\title{
Anxiety and Stress Among Undergraduate Medical Students of Haramaya University, Eastern Ethiopia
}

This article was published in the following Dove Press journal:

Neuropsychiatric Disease and Treatment

\author{
Henock Asfaw' \\ Gelana Fekadu (D) ${ }^{2}$ \\ Mandaras Tariku' \\ Amanuel Oljira ${ }^{2}$ \\ 'Department of Psychiatry, School of \\ Nursing and Midwifery, College of Health \\ and Medical Science, Haramaya \\ University, Harar, Ethiopia; ${ }^{2}$ Department \\ of Nursing, School of Nursing and \\ Midwifery, College of Health and Medical \\ Science, Haramaya University, Harar, \\ Ethiopia
}

Background: The perceived stress and anxiety among medical students have bleak consequences on their academic performances, physical, and psychological wellbeing. However, there is a dearth of reliable epidemiological studies in Ethiopia on medical student's experience of stress and anxiety. Therefore, this study was aimed to determine the prevalence and identify factors associated with stress and anxiety among undergraduate medical students of Haramaya University, Eastern Ethiopia.

Methods: An institutional-based cross-sectional study was conducted from May 13 to June 12, 2019 among 523 participants selected by simple random sampling technique. Data were collected by using structured questionarie through self-adminstered method. Data were entered by Epidata version 3.1 and analyzed using Stastical Package for Social Science(SPSS) version 22. Bivariableand multivariable logistic regression analysis were conducted to identify factors associated with anxiety and stress. Adjusted Odd Ratio (AOR) and 95\% Confidence Interval(CI) was used to show the strength of association, and P-value of 0.05 was used to declare statistical significance.

Results: The prevalence of stress was $44 \%$ (95\% CI: $40.2 \%-48.2 \%$ ) and anxiety was $48.9 \%$ (95\% CI: $44.6 \%-53.3 \%$ ) among undergraduate medical students of Haramaya University. Being female $(\mathrm{AOR}=1.90,95 \% \mathrm{CI}: 1.28-2.81)$ and living off-campus (AOR $=1.75,95 \% \mathrm{CI}: 1.12-2.73)$ were factors significantly associated with both stress and anxiety. Whereas, alcohol use (AOR=2.26, 95\% CI: $1.50-3.50)$ and smoking cigarette $(\mathrm{AOR}=3.50,95 \% \mathrm{CI}: 1.58-7.73)$ linked with stress. The poor psychosocial support $(\mathrm{AOR}=1.93,95 \% \mathrm{CI}$ : $1.20-3.20)$ was significantly associated with anxiety.

Conclusion: Substantially a higher level of stress and anxiety was reported. Being female and living off-campus were linked with both stress and anxiety. Where as, alcohol use and smoking cigarette were associated with stress and poor psychological support was significantly associated with anxiety.

Keywords: stress, anxiety, medical students, Haramaya University, Ethiopia

\section{Introduction}

Stress and anxiety often appear after one another. ${ }^{1}$ But stress is typically caused by an external trigger and it can be a short term. ${ }^{2}$ Anxiety, on the other hand, is defined by persistent excessive worries that do not go away even in the absence of stressors. However, their symptoms are nearly identical. ${ }^{2}$ In common, anxiety and stress results from an interaction between persons and their environment that are perceived as straining or exceeding their adaptive capacities. ${ }^{3}$ Constant exposure to anxious and stressful situations may increase susceptibility to a variety of health problems. ${ }^{4}$ Effects may range from mild, moderate to severe
Correspondence: Gelana Fekadu Department of Nursing, School of Nursing and Midwifery, College of Health and Medical Science, Haramaya

University, Harar, Ethiopia

Tel +251933316505

Email fekadugelana4@gmail.com
Neuropsychiatric Disease and Treatment 2021:17 139-146 
health problems and it depends onstressor's duration and individual's ability to cope. ${ }^{5}$

The medical school environment has been recognized as anxious and stressful for the students due to the curricular and extra-curricular situations. ${ }^{6}$ The perceived stress and anxiety among medical students have negative consequences on their academic performances, physical and psychological well-being. ${ }^{6}$

The prevalence of anxiety and stress among medical students has been reported higher compared to the general population and age-matched peers. Accordingly, the study results from different countries pointed out the prevalence of anxiety and stress among medical students is $37.2 \%$ and $47.1 \%$ in Brazil, ${ }^{7} 50.6 \%$ and $32.8 \%$ in India, ${ }^{8} 62.5 \%$ and $45.1 \%$ in Iraq, ${ }^{9} 63 \%$ and $41 \%$ in Saudi Arabia, ${ }^{10}$ and $64.3 \%$ and $62.4 \%$ in Egypt $^{11}$ respectively.

In Ethiopia, the reported prevalence of anxiety ranges from $30.1 \%$ among Addis Ababa University ${ }^{12}$ to $60.8 \%$ among Arsi University medical students, ${ }^{13}$ whereas, the stress ranges from $40.4 \%$ among Arsi university ${ }^{13}$ to $52.4 \%$ among Jimma university medical students. ${ }^{14}$

Studies showed the level of stress and anxiety experienced by students is elucidated by many factors. Living off-campus, ${ }^{15}$ higher body mass index, ${ }^{11}$ smoking, being female, being first and second-year Students linked with a higher level of both anxiety and stress. ${ }^{10,12,16}$ Likewise, stress among medical students associated with perceived sleeping problem, ${ }^{17}$ living situation, monthly income, and educational level. ${ }^{14}$ Students with poor social support, first and second-year educational levels were more anxious as compared to their counterparts. ${ }^{12}$

Failure to detect the psychological abnormality among medical students may lead to increased mental illness with unwanted outcomes throughout their careers and lives. ${ }^{18}$ Early detection and treatment of such problems will shorten the duration of illness and lessens the long-term social impairment. ${ }^{19}$

Despite few studies ${ }^{12,14,20,21}$ assessed the prevalence and identified risk factors of stress and anxiety among medical students, there is a lack of epidemiologically reliable and study with enough sample size in Ethiopia. Therefore, this study was aimed to determine the prevalence and identify factors associated with stress and anxiety among undergraduate medical students of Haramaya University, Eastern Ethiopia.

\section{Method}

\section{Study Period and Area}

The study was conducted at Haramaya University, College of Health and Medical Science, from May 13 to June 12, 2019. Haramaya University is located in the eastern part of the country at a distance of $510 \mathrm{~km}$ from the capital city, Addis Ababa. The university has two campuses and nine colleges. The Harar campus (College of Health and Medical Science) is found at a distance of 17kilometers away from the main campus. School of medicine emerged as an academic constituent in 2007 and currently, a total of 1315, students are following their education in 2019 (unpublished data. School of medicine, College of Health and Medical Science, Haramaya University).

\section{Study Design and Population}

Institutional based cross-sectional study design was used. All selected undergraduate medical students were included for study and students transferred from other universities and stayed for less than six months at the university were excluded.

\section{Sample Size and Sampling Technique}

Single population proportion formula was used to calculate sample size by considering the assumptions: $\mathrm{n}^{\mathrm{i}}$ : minimum sample size required for the study, $Z=$ standard normal distribution $(\mathrm{Z}=1.96)$ with a confidence interval of $95 \%$ and $\alpha=0.05, P=$ the prevalence anxiety among medical students of Addis Ababa University, 30.1\%, ${ }^{12}$ $\mathrm{d}=$ tolerable margin of error $(\mathrm{d})=4 \%$. The total sample size for this study was 556 with a $10 \%$ non-response rate added. The simple random sampling technique was used to select study participants after proportional allocation of the sample size according to the student's academic year.

\section{Data Collection Tool and Procedure}

The data was collected by using a standardized tool. The socio-demographic characteristics; age, sex, marital status, and living conditions were collected. ASSIST (Alcohol, Smoking and Substance Involvement Screening Test), which was developed by the World Health Organization, was used to assess the psychoactive substance use (WHO). ${ }^{22}$

Depression, anxiety, and stress: Were measured by Depression, Anxiety, and Stress Scale (DASS-21) short form, which has 21 items and seven items each. It was 
the Likert scale ranges from zero to three,computed and multiplied by two. The sum scores of ten and above was indicative of depression, eight and above was indicative of anxiety since, 15 and above was for the stress. ${ }^{23}$

Suicidal history: It was assessed by the module of the world mental health survey initiative version of the WHO and CIDI (Composite International Diagnostic Interview). ${ }^{24}$ Concerning the social support, the Oslothree-item, social support scale was used. ${ }^{25}$ Four psychiatric nurses (bachelor of degree holder) were participated in data collection through self-administered technique and supervised by one psychiatrist (master's degree holder).

\section{Data Quality Control}

Pre-test was done among Dire Dawa University medical students on $5 \%$ (28) of total samples, and relevant modification taken. During the data collection, the questionnaire was checked for its completeness on daily basis by supervisors and investigators. Double data entry was conducted by two independent data clerks, and the proper corrections were made based on the variation between two data clerks.

\section{Data Processing and Analysis}

The data was checked and entered to Epi-Data version 3.1 and exported to SPSS (Statistical Package for Social Science) version 22 for analysis. Descriptive statistics (percentage, mean and standard deviations), bivariable and multivariable binary logistic regression analysis was performed to identify factors associated with stress and anxiety. All variables with a P-value less than 0.25 at bivariable logistic regression analyses were entered into the multivariable logistic regression model, and variables with a P-value less than 0.05 at $95 \%$ confidence interval with their adjusted odds ratio were considered statistically significant.

\section{Results}

\section{Socio-Demographic Characteristics of Participants}

A total of 523 undergraduate medical students were included in the study with a response rate of $94 \%$. The mean age of the students were, 23.62 years $( \pm 2.36 \mathrm{SD})$ with ages ranging from, 19 to 34 years. The majority of the students, $362(69.2 \%)$ were male, $266(50.9 \%)$ orthodox by religion and, 393 (75.1\%) were living in the campus. Regarding their cumulative grade point average, the mean grade of students was, 3.00 with grades
Table I Socio-Demographic Characteristics of Undergraduate Medical Students of Haramaya University, Eastern Ethiopia, 2019 $(\mathrm{N}=523)$

\begin{tabular}{|l|l|l|l|}
\hline Variables & Category & Frequency & Percentage \\
\hline & Mean & $\begin{array}{l}\text { Standard } \\
\text { Deviation }\end{array}$ & \\
\hline CGPA & 3.00 & 0.63 & \\
\hline Age in years & 23.6 & 2.36 & \\
\hline Sex & Male & 362 & 69.2 \\
& Female & 161 & 30.2 \\
\hline Marital status & Single/divorced & 466 & 89.1 \\
& Married & 57 & 10.9 \\
\hline Living situation & In campus & 393 & 75.1 \\
& Off campus & 130 & 24.9 \\
\hline Religion & Orthodox & 266 & 50.9 \\
& Muslim & 135 & 25.8 \\
& Protestant & 104 & 19.9 \\
& Others* & 18 & 3.4 \\
\hline \multirow{2}{*}{ Educational level } & First year & 58 & 11.1 \\
& Second year & 78 & 15.0 \\
& Third year & 89 & 17.0 \\
& Fourth year & 84 & 16.1 \\
& Fifth year & 99 & 22.0 \\
\hline Sixth year & 115 & \\
\hline
\end{tabular}

Note: *Wakefata, Atheist, Catholic, Jehovah witness and Apostle.

ranging from, 1.83 to 3.87 and, $115(22 \%)$ students were 6 th year, followed by 5 th year, $99(19 \%)$ in the medical school (Table 1).

\section{Substance Use History}

About,146 (27.9\%) students have been consuming alcohol and, $41(7.8 \%)$ students were smoking cigarette in the past, 3 months (Figure 1).

\section{Clinical and Psychosocial Characteristics}

A total of, 228 (43.6\%) students had depressive symptoms, $120(22.9 \%)$ had suicidal ideation, and, 22 (4.2\%) had a suicidal attempt. Around, 223 (42.6\%) students reported moderate perceived social support (Table 2).

\section{Prevalence of Stress and Anxiety}

The prevalence of stress was, 230(44\%) (95\% CI: $40.2 \%-$ $48.4 \%$ ) and anxiety was, 256(48.9\%) (95\% CI: $44.6 \%$ $-53.3 \%$ ) among undergraduate medical students (Figure 2). 


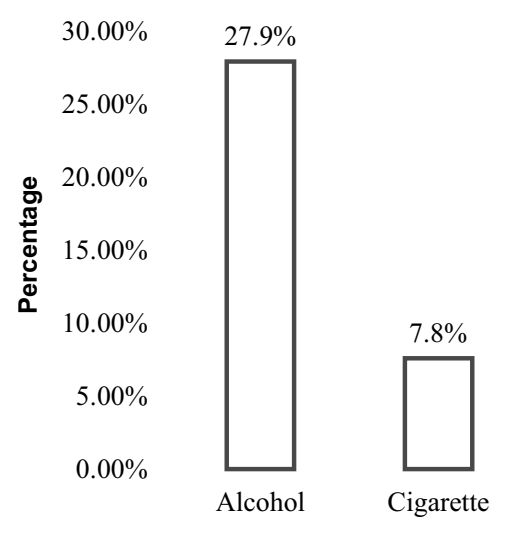

Current substance use

Figure I Substance use characteristics of undergraduate medical students of Haramaya University, Eastern Ethiopia, 2019 ( $N=523)$.

Among students with stress, 61\% were males and, $60.5 \%$ were among those with anxiety (Table 3 ).

\section{Factors Associated with Stress and Anxiety}

During the bivariable analysis; sex, marital status, living situation, family history of suicidal attempt, family history of mental illness, current alcohol use, current cigarette use, and current khat use fulfilled the minimum requirement

Table 2 Clinical and Psychosocial Characteristics of Undergraduate Medical Students of Haramaya University, Eastern Ethiopia, 2019 ( $\mathrm{N}=523)$

\begin{tabular}{|l|l|l|l|}
\hline Variables & Category & Frequency & Percentage \\
\hline Depressive & Yes & 228 & 43.6 \\
No & 295 & 56.4 \\
\hline Suicidal ideation & Yes & 120 & $\begin{array}{l}22.9 \\
77.1\end{array}$ \\
\hline No & 403 & $\begin{array}{l}\text { Noicidal attempt } \\
\text { Yes }\end{array}$ & $\begin{array}{l}22 \\
501\end{array}$ \\
\hline $\begin{array}{l}\text { Family history of } \\
\text { suicidal attempt }\end{array}$ & Yes & 41 & $\begin{array}{l}\text { No } \\
482\end{array}$ \\
\hline $\begin{array}{l}\text { Family history of } \\
\text { committed suicide }\end{array}$ & Yes & 22 & 92.2 \\
\hline Family history of mental & Yes & 501 & $\begin{array}{l}4.2 \\
95.8\end{array}$ \\
\hline illness & No & 466 & $\begin{array}{l}10.9 \\
89.1\end{array}$ \\
\hline $\begin{array}{l}\text { Perceived social } \\
\text { support }\end{array}$ & $\begin{array}{l}\text { Poor } \\
\text { Moderate } \\
\text { Strong }\end{array}$ & $\begin{array}{l}192 \\
108\end{array}$ \\
\hline
\end{tabular}

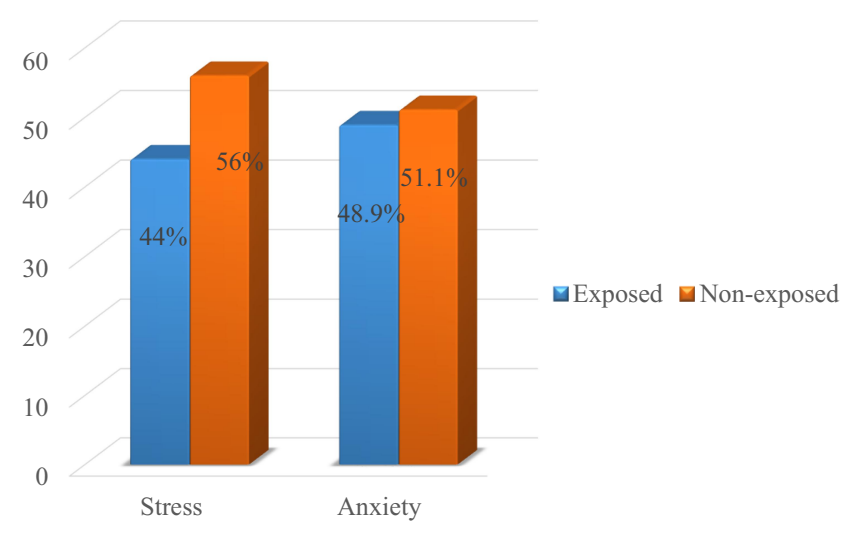

Figure 2 Prevalence of stress and anxiety of undergraduate medical students of Haramaya University, Eastern Ethiopia, 2019 ( $N=523)$.

(P-value less than 0.25) and were taken into a multivariable logistic regression model to control confounding factors.

From the multivariable logistic regression analysis being female, living off-campus, current alcohol use, current cigarette use, and poor social support were found to be statistically significant at P-value less than 0.05 .

According to the current study female students experience stress; 1.9 times (AOR=1.90, 95\% CI: 1.28-2.81) and anxiety; 2.1 times $(\mathrm{AOR}=2.10,95 \% \mathrm{CI}$ : $1.40-3.10)$ more likely than male students. The odds of having stress and anxiety among students who were living off-campus were 1.75 times $(\mathrm{AOR}=1.75,95 \% \mathrm{CI}: 1.12-2.73)$ and 2.21 times $(\mathrm{AOR}=2.21$, 95\% CI: 1.42-3.44) higher as compared to the students who were living in the campus respectively. Those students using alcohol were 2.28 times $(\mathrm{AOR}=2.26,95 \% \mathrm{CI}: 1.50-3.50)$ more likely to experience stress as compared to non-

Table 3 Prevalence of Stress and Anxiety Among Undergraduate Medical Students of Haramaya University, Eastern Ethiopia

\begin{tabular}{|l|l|l|l|}
\hline \multicolumn{2}{|l|}{ Characteristics } & Stress & Anxiety \\
\hline Sex & Male & $61 \%$ & $60.5 \%$ \\
& Female & $39 \%$ & $39.5 \%$ \\
\hline Living situation & In campus & $69.5 \%$ & $66.7 \%$ \\
& Off campus & $30.5 \%$ & $33.3 \%$ \\
\hline Marital status & Married & $9 \%$ & $12.5 \%$ \\
& Single & $91 \%$ & $87.5 \%$ \\
\hline Current alcohol use & Yes & $37.8 \%$ & $33 \%$ \\
& No & $62.2 \%$ & $67 \%$ \\
\hline Current khat use & Yes & $23 \%$ & $72.6 \%$ \\
& No & $77 \%$ & $27.4 \%$ \\
\hline Current cigarette use & Yes & $13 \%$ & $9.3 \%$ \\
& No & $87 \%$ & $90.7 \%$ \\
\hline
\end{tabular}


alcoholic students. Similarly, students who smoke cigarettes were 3.5 times (AOR=3.50, 95\% CI: 1.58-7.73) more likely to have anxiety as compared to nonsmokers. Whereas, students with poor social support were 1.93 times $(\mathrm{AOR}=1.93$, 95\% CI: $1.20-3.20$ ) more likely to have anxiety as compared with students with strong social support (Table 4).

\section{Discussion}

This study determined the prevalence and identified the factors associated with stress and anxiety among undergraduate medical students of Haramaya University. Hence, the overall prevalence of stress and anxiety was, 44\% (95\% CI: 40.2\%$48.4 \%$ ) and $48.9 \%$ (95\% CI: $44.6 \%-53.3 \%$ ) respectively. This is in line with the study finding from Turkey, $47.1 \%$ for anxiety, ${ }^{16}$ Hong Kong University, $54.4 \%$ for anxiety ${ }^{26}$ and Malaysia, $41.9 \%$ for stress. ${ }^{27}$ However, the current finding is lower as compared to the study finding by Abdallah et al (2014) with the prevalence of stress, $57.8 \%$, and anxiety, $78.4 \% .{ }^{28}$ Similar studies from other countries showed far higher rates of stress and anxiety among medical students; in
Egypt, stress, $62.4 \%$ and Anxiety, $64.3 \%{ }^{11}$ in Saud Arabia, stress, $71.9 \% .{ }^{17}$ This variation could be attributed to sociocultural differences, and the tools used for the study. ${ }^{11}$

The study finding from Jordan ${ }^{29}$ and Michigan University reported a lower level of anxiety, $13.58 \%$ and $15.6 \%$ among university students respectively ${ }^{30}$ as compared to our study finding. This could be linked with the fact that students in a developed country may have less financial hardship compared to those students in low-income countries including Ethiopia. $^{31}$

This study identified gender difference in the self-reported level of stress and anxiety with much higher among female students. This finding is in consonance with study results conducted among Egyptian and Turkish female students reporting a higher level of stress and anxiety. ${ }^{11,28}$ This is possibly due to the fact that females complain more about the high load of the curriculum and they are also more likely to report the stress, physical and psychological symptoms. ${ }^{32}$ Additionally, the study result conducted among a sample of college students in the United States of America outlined the

Table 4 Factors Associated with Stress and Anxiety Among Undergraduate Medical Students of Haramaya University, Eastern Ethiopia, 2019

\begin{tabular}{|c|c|c|c|c|c|c|c|c|c|}
\hline \multicolumn{2}{|l|}{ Characteristics } & \multicolumn{2}{|c|}{ Stress } & \multirow{2}{*}{$\begin{array}{l}\text { COR } \\
(95 \% \mathrm{Cl})\end{array}$} & \multirow{2}{*}{$\begin{array}{l}\text { AOR } \\
(95 \% \mathrm{CI})\end{array}$} & \multicolumn{2}{|c|}{ Anxiety } & \multirow[t]{2}{*}{$\operatorname{COR}(95 \% \mathrm{Cl})$} & \multirow[t]{2}{*}{$\operatorname{AOR}(95 \% \mathrm{Cl})$} \\
\hline & & Yes & No & & & Yes & No & & \\
\hline Sex & $\begin{array}{l}\text { Male } \\
\text { Female }\end{array}$ & $\begin{array}{l}140 \\
90\end{array}$ & $\begin{array}{l}222 \\
71\end{array}$ & $\begin{array}{l}1 \\
2.01(1.38-2.93)\end{array}$ & $\begin{array}{l}1.90(1.28-2.81)^{*}\end{array}$ & $\begin{array}{l}155 \\
101\end{array}$ & $\begin{array}{l}207 \\
60\end{array}$ & $\begin{array}{l}1 \\
2.25(1.54-3.30)\end{array}$ & $\begin{array}{l}\text { I } \\
2.1(1.40-3.10)^{* *}\end{array}$ \\
\hline Living situation & $\begin{array}{l}\text { In campus } \\
\text { Off campus }\end{array}$ & $\begin{array}{l}160 \\
70\end{array}$ & $\begin{array}{l}233 \\
60\end{array}$ & $\begin{array}{l}1 \\
1.70(1.14-2.53)\end{array}$ & $\begin{array}{l}\text { I } \\
1.75(1.12-2.73)^{*}\end{array}$ & $\begin{array}{l}171 \\
85\end{array}$ & $\begin{array}{l}222 \\
45\end{array}$ & $\begin{array}{l}\text { I } \\
2.45(I .62-3.71)\end{array}$ & $\begin{array}{l}1 \\
2.21(1.42-3.44)^{*}\end{array}$ \\
\hline Marital status & $\begin{array}{l}\text { Married } \\
\text { Single }\end{array}$ & $\begin{array}{l}21 \\
209\end{array}$ & $\begin{array}{l}36 \\
257\end{array}$ & $\begin{array}{l}1 \\
1.40(0.80-2.50)\end{array}$ & $\begin{array}{l}\text { I } \\
\text { I.770.94-3.33) }\end{array}$ & $\begin{array}{l}32 \\
224\end{array}$ & $\begin{array}{l}25 \\
242\end{array}$ & $\begin{array}{l}1 \\
0.72(0.42-1.30)\end{array}$ & $\begin{array}{l}1 \\
1.02(0.60-1.90)\end{array}$ \\
\hline Family history of suicidal attempt & $\begin{array}{l}\text { Yes } \\
\text { No }\end{array}$ & $\begin{array}{l}22 \\
208\end{array}$ & $\begin{array}{l}19 \\
274\end{array}$ & $\begin{array}{l}1.53(0.80-2.90) \\
1\end{array}$ & $\begin{array}{l}\text { I. } 10,(0.52-2.30) \\
\text { । }\end{array}$ & $\begin{array}{l}26 \\
230\end{array}$ & $\begin{array}{l}15 \\
252\end{array}$ & $\begin{array}{l}1.90(0.98-3.70) \\
1\end{array}$ & $\begin{array}{l}1.28(0.60-2.80) \\
1\end{array}$ \\
\hline Family history of mental illness & $\begin{array}{l}\text { Yes } \\
\text { No }\end{array}$ & $\begin{array}{l}31 \\
199\end{array}$ & $\begin{array}{l}26 \\
267\end{array}$ & $\begin{array}{l}1.60(0.92-2.80) \\
1\end{array}$ & $\begin{array}{l}1.75(0.92-3.32) \\
\mathrm{I}\end{array}$ & $\begin{array}{l}36 \\
220\end{array}$ & $\begin{array}{l}21 \\
246\end{array}$ & $\begin{array}{l}1.92(1.10-3.38) \\
1\end{array}$ & $\begin{array}{l}1.90(0.90-3.64) \\
1\end{array}$ \\
\hline Current alcohol use & $\begin{array}{l}\text { Yes } \\
\text { No }\end{array}$ & $\begin{array}{l}87 \\
143\end{array}$ & $\begin{array}{l}59 \\
234\end{array}$ & $\begin{array}{l}2.40(1.63-3.60) \\
1\end{array}$ & $\begin{array}{l}2.28(1.50-3.50) * * \\
\text { । }\end{array}$ & $\begin{array}{l}82 \\
174\end{array}$ & $\begin{array}{l}64 \\
203\end{array}$ & $\begin{array}{l}1.50(1.02-2.20) \\
1\end{array}$ & $\begin{array}{l}1.50(0.94-2.21) \\
1\end{array}$ \\
\hline Current khat use & $\begin{array}{l}\text { Yes } \\
\text { No }\end{array}$ & $\begin{array}{l}53 \\
177\end{array}$ & $\begin{array}{l}52 \\
241\end{array}$ & $\begin{array}{l}1.40,(0.90-2.13) \\
1\end{array}$ & $\begin{array}{l}0.75(0.45-1.25) \\
\mathrm{I}\end{array}$ & & & & \\
\hline Current cigarette use & $\begin{array}{l}\text { Yes } \\
\text { No }\end{array}$ & $\begin{array}{l}30 \\
200\end{array}$ & $\begin{array}{l}11 \\
282\end{array}$ & $\begin{array}{l}3.85(1.90-7.86) \\
1\end{array}$ & $\begin{array}{l}3.50(1.58-7.73)^{*} \\
\text { । }\end{array}$ & $\begin{array}{l}24 \\
232\end{array}$ & $\begin{array}{l}17 \\
250\end{array}$ & $\begin{array}{l}1.52(0.80-2.90) \\
\text { । }\end{array}$ & $\begin{array}{l}1.10(0.53-2.20) \\
1\end{array}$ \\
\hline Perceived social support & $\begin{array}{l}\text { Strong } \\
\text { Moderate } \\
\text { Poor }\end{array}$ & & & & & $\begin{array}{l}43 \\
102 \\
111\end{array}$ & $\begin{array}{l}65 \\
121 \\
81\end{array}$ & $\begin{array}{l}\text { I } \\
\text { I.27(0.80-2.03) } \\
2.07(1.28-3.35)\end{array}$ & $\begin{array}{l}\text { I } \\
1.30(0.80-2.10) \\
1.93(1.20-3.20)\end{array}$ \\
\hline
\end{tabular}

Notes: ${ }^{*} p<0.05$ and ${ }^{*} \mathrm{p}<0.001$.

Abbreviations: COR, crude odds ratio; AOR, adjusted odds ratio. 
body image and lower self-esteem was the significant contributor of stress and anxiety among females. ${ }^{15}$

Our current study suggests the living situation of students contributes to stress and anxiety. Students living offcampus were reported more stress and anxiety than those who are living in a campus dormitory. This is in agreement with previous study findings. ${ }^{30,33-36}$ This could be linked with the fact that students live off-campus were responsible to pay monthly house rent, prepare or buy daily meals and deal any issues raised related to the house or apartment they live in. ${ }^{15}$ There is also evidences that living alone is the risk factor for stress and anxiety. ${ }^{37,38}$ So the university has to give psychosocial support for students living off-campus. The students also need to get ready before they plan to live off-campus. ${ }^{30}$

Good social support is perceived to have a positive effect on health and defined as through which social relationships promote health and well-being. ${ }^{39}$ Our study finding also delineated students who have poor social support were more anxious than students who have good social support. This is in agreement with the previous study results. ${ }^{40,41}$ Hamadan et al (2008) also depicted that University students who have a lower perception of social support are expected to have a higher perception of life events as anxious situations. ${ }^{42}$

Both social cognitive and stress environment model emphasizes the reciprocated association among physiological, cognitive, behavioral, and socio-environmental factors that can both cause stress symptoms as well as mediate effective coping responses to stressors. ${ }^{43}$ Evidences also showed up the relationship between stress and alcohol looks like a vicious circle. ${ }^{44,45}$ Stress is a significant motivator for university students to drink alcohol or smoke cigarettes as a coping mechanism. Despite, it is not merely the reason, occasional celebration, peer pressure, and social acceptance were raised. ${ }^{46}$ Reciprocally the intended coping mechanism may lead to stress.

Our study finding also highlighted students who drink alcohol and smoke cigarette were more likely to experience stress than their counterparts. This is supported by previously conducted study results which revealed the excessive alcohol consumption and smoking cigarette, which is considered as a coping response, in turn, have exacerbated the stress symptoms. ${ }^{47}$ The ill-effects of the substance abuse among medical students, were not limited to the psychological stress but lead to physical impairment, poor interpersonal relationships and poor academic performance. ${ }^{46}$

This study was not without limitation. Its cross-sectional nature may fail to capture the long-term cause and effect relationship. The study was also conducted in one university and might not be generalized to whole university students. Despite these limitations, the study expanded our knowledge on the prevalence and factors associated with stress and anxiety among undergraduate medical students of Haramaya University. It also provides an insight for the Haramaya University administrators and stakeholders to tackle the problem. Additionally, the current finding might help as baseline data for further studies with advanced methods and multi centers.

\section{Conclusion}

The study depicted the higher prevalence of stress and anxiety among undergraduate medical students of Haramaya University. Being female gender, living off-campus, perceived poor social support, using alcohol and cigarette were associated with stress and anxiety. The establishment of students' counseling, behavioral change, and communication unit in medical schools, promoting student wellbeing, providing supportive, preventive, and curative psychosocial services to enable students to cope with their new phase of life is recommended. Medical schools have to encourage students to spend more time on their social lives and provide them with coping tools to overcome stress throughout their medical education. There should be special attention given to female students and those living off-campus. Leisure activities should be included in the curriculum to promote better interaction between the students and their medical environment.

\section{Abbreviations}

AOR, adjusted odds ratio; ASSIST, Alcohol; Smoking and Substance Involvement Screening Test; CPGA, Cumulative Grade Point Average; CI, Confidence Interval; CIDI, Composite International Diagnostic Interview; COR, Crude Odds Ratio; DASS, Depression; Anxiety; Stress Scale; SD, standard deviation.

\section{Data Sharing Statement}

The datasets used for analysis are available from the corresponding author upon a reasonable request.

\section{Ethical Approval}

This study was conducted in accordance with the Declaration of Helsinki-Ethical principle for medical research involving the human subjects. Accordingly, the ethical clearance was obtained from a joint ethical review committee of the University of Gondar and Amanuel mental specialized hospital. A formal letter was obtained from the University of Gondar 
and submitted to Haramaya University, College of Health and Medical Science for administrative approval. Written informed consent was obtained from the students prior to the data collection by explaining the purpose of the study. Those who did not wish to take part could be allowed either to withdraw from the study at any time they want. All informations collected from the subjects were handled confidentially.

\section{Acknowledgments}

We are grateful to data collectors for their admirable endeavor during the data collection. Also, our appreciation goes to study participants for their participation.

\section{Author Contributions}

All authors made a significant contribution to the work reported, whether that is in the conception, study design, execution, acquisition of data, analysis and interpretation, or in all these areas; took part in drafting, revising or critically reviewing the article; gave final approval of the version to be published; have agreed on the journal to which the article has been submitted; and agree to be accountable for all aspects of the work.

\section{Funding}

The study was funded by the University of Gonder. But, the funding institution has no role on the consent for publication.

\section{Disclosure}

The authors declare that they have no conflicts of interest for this study.

\section{References}

1. Maurer J, Rebbapragada V, Borson S, et al. Anxiety and depression in COPD: current understanding, unanswered questions, and research needs. Chest. 2008;134(4):43S-56S. doi:10.1378/chest.08-0342

2. Association. AP. What's the Difference Between Stress and Anxiety?; 2020.

3. Swaminathan A, Viswanathan S, Gnanadurai T, Ayyavoo S, Manickam T. Perceived stress and sources of stress among first-year medical undergraduate students in a private medical college-Tamil Nadu. Natl $J$ Physiol Pharm Pharmacol. 2016;6(1):9-14. doi:10.5455/njppp.2015.5.1909201574

4. Tabalipa F, Souza M, Pfützenreuter G, Lima VC, Traebert E, Traebert J. Prevalence of anxiety and depression among medical students. Revista Brasileira De Educação Médica. 2015;39 (3):388-394. doi:10.1590/1981-52712015v39n3e02662014

5. Shin LM, Liberzon I. The neurocircuitry of fear, stress, and anxiety disorders. Neuropsychopharmacology. 2010;35(1):169-191.

6. Solanky P, Desai B, Kavishwar A, Kantharia S. Study of psychological stress among undergraduate medical students of government medical college, Surat. Int J Med Sci Public Health. 2012;1(2):38-42. doi:10.5455/ijmsph.2012.1.38-42
7. Moutinho ILD, Maddalena N, Roland RK, et al. Depression, stress and anxiety in medical students: a cross-sectional comparison between students from different semesters. Revista Da Associação Médica Brasileira. 2017;63(1):21-28. doi:10.1590/1806-9282.63.01.21

8. Kumar SD, Kavitha H, Kulkarni P, Siddalingappa H, Manjunath R. Depression, anxiety and stress levels among medical students in Mysore, Karnataka, India. Int J Community Med Public Heal. 2016;359-362. doi:10.18203/2394-6040.ijcmph20151591

9. Rasheed AG, Hussein AG. Depression, anxiety, and stress among medical students of College of Medicine, Hawler Medical University, Erbil, Iraq. Zanco J Med Sci. 2019;23(2):143-152. doi:10.15218/ zjms.2019.019

10. Kulsoom B, Afsar NA. Stress, anxiety, and depression among medical students in a multiethnic setting. Neuropsychiatr Dis Treat. 2015;11:1713. doi:10.2147/NDT.S83577

11. Wahed WYA, Hassan SK. Prevalence and associated factors of stress, anxiety and depression among medical Fayoum University students. Alexandria J Med. 2017;53(1):77-84. doi:10.1016/j.ajme.2016.01.005

12. Kebede MA, Anbessie B, Ayano G. Prevalence and predictors of depression and anxiety among medical students in Addis Ababa, Ethiopia. Int $J$ Ment Health Syst. 2019;13(1):30. doi:10.1186/ s13033-019-0287-6

13. Melaku L, Bulcha G. The depression, anxiety, and stress and their sociodemographic correlates among undergraduate medical students of Arsi University, Southeast Ethiopia. Int J Health Allied Sci. 2020;9 (2):105. doi:10.4103/ijhas.IJHAS_81_19

14. Melaku L, Mossie A, Negash A. Stress among medical students and its association with substance use and academic performance. J Biomed Educ. 2015;2015:1-9. doi:10.1155/2015/149509

15. Beiter R, Nash R, McCrady M, et al. The prevalence and correlates of depression, anxiety, and stress in a sample of college students. J Affect Disord. 2015;173:90-96. doi:10.1016/j.jad.2014.10.054

16. Bayram N, Bilgel N. The prevalence and socio-demographic correlations of depression, anxiety and stress among a group of university students. Soc Psychiatry Psychiatr Epidemiol. 2008;43(8):667-672. doi:10.1007/s00127-008-0345-x

17. Sani M, Mahfouz M, Bani I, et al. Prevalence of stress among medical students in Jizan University, Kingdom of Saudi Arabia. Gulf Med J. 2012;1(1):19-25.

18. Tyssen R, Vaglum P, Grønvold NT, Ekeberg Ø. Suicidal ideation among medical students and young physicians: a nationwide and prospective study of prevalence and predictors. J Affect Disord. 2001;64(1):69-79. doi:10.1016/S0165-0327(00)00205-6

19. Pignone MP, Gaynes BN, Rushton JL, et al. Screening for depression in adults: a summary of the evidence for the US Preventive Services Task Force. Ann Intern Med. 2002;136(10):765-776. doi:10.7326/ 0003-4819-136-10-200205210-00013

20. Melese B, Bayu B, Wondwossen F, et al. Prevalence of mental distress and associated factors among Hawassa University medical students, Southern Ethiopia: a cross-sectional study. BMC Res Notes. 2016;9(1):485. doi:10.1186/s13104-016-2289-7

21. Tsegay L, Tesfaye G, Ayano G. The prevalence and associated factors of suicidal attempt among medical students in Addis Ababa Ethiopia. Psychiatric Quarterly. 2020;1-13.

22. WHO. Group, WHO ASSIST Working The alcohol, smoking and substance involvement screening test (ASSIST): development, reliability and feasibility. Addiction. 2002;97(9):1183-1194. doi:10.1046/ j.1360-0443.2002.00185.x

23. Lovibond PF, Lovibond SH. The structure of negative emotional states: comparison of the Depression Anxiety Stress Scales (DASS) with the Beck Depression and Anxiety Inventories. Behav Res Ther. 1995;33(3):335-343. doi:10.1016/0005-7967(94)00075-U

24. Gelaye B, Williams MA, Lemma S, et al. Diagnostic validity of the composite international diagnostic interview (CIDI) depression module in an East African population. Int J Psychiatry Med. 2013;46 (4):387-405. doi:10.2190/PM.46.4.e 
25. Dalgard OS, Dowrick C, Lehtinen V, et al. Negative life events, social support and gender difference in depression. Soc Psychiatry Psychiatr Epidemiol. 2006;41(6):444-451. doi:10.1007/s00127-0060051-5

26. Lun KW, Chan C, Ip PK, et al. Depression and anxiety among university students in Hong Kong. Hong Kong Med J. 2018;24 (5):466-472. doi:10.12809/hkmj176915

27. Sherina M, Rampal L, Kaneson N. Psychological stress among undergraduate medical students. Med J Malaysia. 2004;59(2):207-211.

28. Abdallah AR, Gabr HM. Depression, anxiety and stress among first year medical students in an Egyptian public university. Int Res J Med Med Sci. 2014;2(1):11-19.

29. Al-Omari WM, Al-Omiri MK. Dental anxiety among university students and its correlation with their field of study. J Appl Oral Sci. 2009;17(3):199-203. doi:10.1590/S1678-77572009000300013

30. Eisenberg D, Gollust SE, Golberstein E, Hefner JL. Prevalence and correlates of depression, anxiety, and suicidality among university students. Am j Orthopsychiatry. 2007;77(4):534-542. doi:10.1037/ 0002-9432.77.4.534

31. Yusoff MSB, Rahim AFA, Baba AA, Ismail SB, Pa MNM. Prevalence and associated factors of stress, anxiety and depression among prospective medical students. Asian J Psychiatr. 2013;6 (2):128-133. doi:10.1016/j.ajp.2012.09.012

32. Bostanci M, Ozdel O, Oguzhanoglu NK, et al. Depressive symptomatology among university students in Denizli, Turkey: prevalence and sociodemographic correlates. Croat Med J. 2005;46(1):96-100.

33. Gillman JL, Kim HS, Alder SC, Durrant LH. Assessing the risk factors for suicidal thoughts at a nontraditional commuter school. J Am College Health. 2006;55(1):17-26. doi:10.3200/JACH.55.1.17-26

34. Lester D. Depression and suicidal ideation in college students: a preliminary study of campus variables. Psychol Rep. 2013;112 (1):106-108. doi:10.2466/12.02.10.PR0.112.1.106-108

35. Omokhodion F, Gureje O. Psychosocial problems of clinical students in the University of Ibadan Medical School. Afr J Med Med Sci. 2003;32(1):55.

36. Othieno CJ, Okoth RO, Peltzer K, Pengpid S, Malla LO. Depression among university students in Kenya: prevalence and sociodemographic correlates. J Affect Disord. 2014;165:120-125. doi:10.1016/ j.jad.2014.04.070
37. Cornwell EY, Waite LJ. Social disconnectedness, perceived isolation, and health among older adults. J Health Soc Behav. 2009;50 (1):31-48. doi:10.1177/002214650905000103

38. Soysa CK, Wilcomb CJ. Mindfulness, self-compassion, self-efficacy, and gender as predictors of depression, anxiety, stress, and well-being. Mindfulness. 2015;6(2):217-226. doi:10.1007/s12671013-0247-1

39. Cohen S, Underwood L, Gottlieb B. Measuring and intervening in social support. Social Relationships Health. 2000;3-25.

40. Chao RCL. Managing perceived stress among college students: the roles of social support and dysfunctional coping. $J$ College Counseling. 2012;15(1):5-21. doi:10.1002/j.2161-1882.2012.00002.x

41. Osborn TL, Venturo-Conerly KE, Wasil AR, Schleider JL, Weisz JR. Depression and anxiety symptoms, social support, and demographic factors among Kenyan high school students. J Child Fam Stud. 2020;29(5):1432-1443. doi:10.1007/s10826-019-01646-8

42. Hamdan-Mansour AM, Dawani HA. Social support and stress among university students in Jordan. Int $J$ Ment Health Addict. 2008;6 (3):442-450. doi:10.1007/s11469-007-9112-6

43. Gordon HW. Early environmental stress and biological vulnerability to drug abuse. Psychoneuroendocrinology. 2002;27(1-2):115-126. doi:10.1016/S0306-4530(01)00039-7

44. Bandura A. Health promotion by social cognitive means. Health Educ Behav. 2004;31(2):143-164. doi:10.1177/1090198104263660

45. Cook RF, Back AS, Trudeau J, McPherson T. Integrating substance abuse prevention into health promotion programs in the workplace: a social cognitive intervention targeting the mainstream user. 2003.

46. Arora A, Kannan S, Gowri S, Choudhary S, Sudarasanan S, Khosla P. Substance abuse amongst the medical graduate students in a developing country. Indian J Med Res. 2016;143(1):101. doi:10.4103/0971-5916.178617

47. O'hare T, Sherrer MV. Co-occurring stress and substance abuse in college first offenders. J Hum Behav Soc Environ. 2000;3(1):29-44. doi:10.1300/J137v03n01_02

\section{Publish your work in this journal}

Neuropsychiatric Disease and Treatment is an international, peerreviewed journal of clinical therapeutics and pharmacology focusing on concise rapid reporting of clinical or pre-clinical studies on a range of neuropsychiatric and neurological disorders. This journal is indexed on PubMed Central, the 'PsycINFO' database and CAS, and is the official journal of The International Neuropsychiatric Association (INA). The manuscript management system is completely online and includes a very quick and fair peer-review system, which is all easy to use. Visit http://www.dovepress.com/testimonials.php to read real quotes from published authors.

Submit your manuscript here: https://www.dovepress.com/neuropsychiatric-disease-and-treatment-journal 